\title{
ROLE OF MACROPHAGES AS POSSIBLE TRANSPORTERS OF Plasmodium yoelII NIGERIENSIS MEROZOITES through the lymphatic system. Preliminary note
}

\author{
MORA-SILVERA E.*, COQUELIN F.*, VUONG P.**, DEHARO E.*, GAUTRET P.*, RENIA L.***, \\ CHABAUD A.* \& LANDAU I.*
}

\section{Summary :}

Vesicles containing apparently healthy merozoites from mature schizonts were observed in the spleen and lymph nodes of mice parasitized by Plasmodium yoelii nigeriensis. They differed from all parasitic stages undergoing digestion by the macrophage and from mature schizonts of the blood. Up to 40 merozoites from three mature schizonts may be seen in the same compartment. They are thought to be accumulations of latent merozoites.

KEY WORDS : Plasmodium yoelii nigeriensis, macrophages, vesicles of latent merozoites, lymphatics.
Many observations on the rhythm of the blood schizogony of murine Plasmodium have been made recently (see review by Landau and Chabaud, 1994). Each species showed unexpected individual features which can only be understood if the existence of latent merozoites i. e. merozoites which do not penetrate immediately into new red blood cells (RBCs) after their release from the schizont, is assumed.

This assumption was contradicted by the fact that in vitro, extra-cellular merozoites very quickly lose their infectivity (Johnson et al., 1980). We were then led to suspect that they persist in the lymphatic system, a fact that was later directly corroborated by the histological examination of lymphatic tissues (Landau et al., 1995). Many stages of Plasmodium were found in the small lymphatic vessels and in the thoracic duct, mostly extra-cellular. Trophozoites are unlikely to survive and develop extra-cellularly and the most likely extra-cel-

\footnotetext{
* Laboratoire de Biologie Parasitaire, Helminthologie, Protozoologie (CNRS ERS 156) et Laboratoire de Protozoologie et Parasitologie comparée (EPHE), Muséum National d'Histoire Naturelle, 61, rue Buffon, 75231 Paris Cedex 05

** Unité d'Anatomie et de Cytologie pathologique, Hôpital SaintMichel, 33, rue Olivier de Serres, 75015 Paris.

*** Unité INSERM U313, Hôpital de la Pitié Salpêtrière, Bd de l'Hôpital, 75005 Paris.

Correspondence: I. Landau.
}

Résumé : RÔLE VRAISEMBLABLE DES MACROPHAGES DANS LE TRANSPORT DES MÉROZOÏTES DE PlaSMODIUM DANS LE RÉSEAU LYMPHATIQUE. NOTE PRÉLIMINAIRE

Des loges contenant des mérozoiltes apparemment sains, provenant de schizontes mûrs, ont été observés dans la rate et les ganglions lymphatiques de souris infectées avec Plasmodium yoelii nigeriensis. Ces éléments se différencient aisément de tous les stades parasitaires en cours de digestion par les macrophages et des schizontes mûrs observés dans le sang. Jusqu'à 40 mérozoiltes provenant de trois schizontes peuvent être observés dans le même compartiment. Ces formations pourraient constituer un état latent des mérozoites dans le réseau lymphatique.

MOTS CLÉS : Plasmodium yoelii nigeriensis, macrophages, loges de merozoiltes latents, lymphatiques.

lular resistance stage is the merozoite. However an important question remains to be answered: how does the merozoite preserve its latency?: isolated and naked in the lymphatic fluid? attached to others in a mature schizont? by phoresis inside a cell of the parasitized animal? The following preliminary observations show that the latter hypothesis should be considered as one of the possible mechanisms.

\section{MATERIALS AND METHODS}

\section{DESCRIPTION OF PARASITES}

T $\mathrm{n}$ the spleen and less frequently in lymph nodes, particular parasitic forms were observed in mice heavily infected with $P . y$. nigeriensis, sometimes as soon as the fourth day post inoculation, but principally in late infections. These structures which may be scanty or sometimes very abundant, are described below (Fig. 1) in Bouin fixed impression smears of spleen and lymph nodes and in sections of Carnoy fixed tissues, both stained by the Giemsa-colophonium method.

In many instances, in the spleen of intact mice as well as in the lymph nodes of splenectomized and intact animals, a sort of white, round, well limited pocket, containing one or several mature and ruptured schizonts, with their merozoites scattered inside the cavity, 

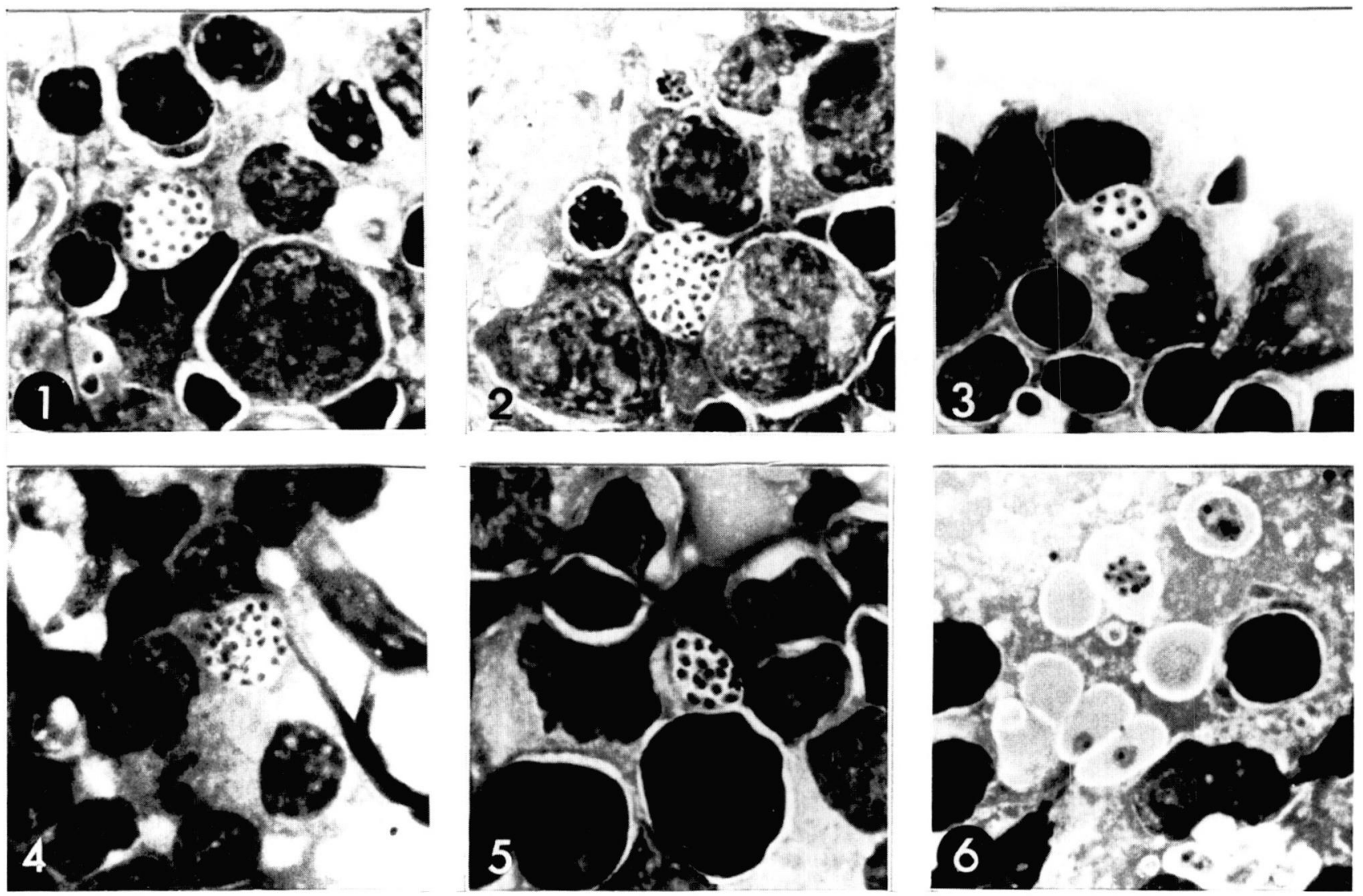

Fig. 1. - Impression smears of the spleen of mice infected with Plasmodium yoelii nigeriensis; 1-5: vesicles containing eight to forty merozoites; 6: schizont inside a red blood cell.

were seen inside a macrophage or apparently extracellularly. Other phagocytised elements were sometimes present inside the host cell allowing its identification.

In the impression smears, up to 40 merozoites were seen inside this pocket together with one, two or three pigment masses identical to those seen in the mature schizonts of the blood. There was no sign of degeneration or indication that a process of digestion was going on. Some of these collections of merozoites were extra-cellular and it was not possible to determine if they were free in the lymph or released from a macrophage when the tissue was smeared.

In the sections they were more difficult to detect; however a few were seen inside a white cell sitting close to the external side of the cortico-medullar sinus endothelium.

They differed from schizonts undergoing destruction in the macrophages by the absence of any sign of red blood cell, by their regular outline and round shape, by their dispersion in the compartment, their healthy appearance and normal staining affinities.

When apparently extra-cellular, they differ from the schizonts seen in the adjoining red blood cells by remaining enclosed in a round and well limited, vesicle that is apparently empty except for the merozoites dispersed in it and some pigment granules.

The presence of one, two or three pigment masses is evidence that the merozoites came from the aggregation of one to three mature schizonts.

\section{IDENTIFICATION OF MACROPHAGES}

Spleen from an infected mouse was fixed with Carnoy's fluid and embedded before sectionning. After the removal of paraffin and rehydration, sections were dried and frozen. In order to detect macrophages, sections were fixed in cold methanol, rinsed in PBS and pre-incubated with PBS containing $5 \%$ fetal calf serum (Sigma, Saint-Quentin l'Arbresle, France) for 30 minutes and rinsed three times with PBS. Two different monoclonal antibodies, Mac-1 and Mac-2 (Hybridomas M1/70 and M3/38 obtained from ATCC Rockville, MD) against mouse macrophage antigens were further used as a dilution (1:10) of culture supernatant. Based on previous studies (Ho and Springer, 1984) it is known that Mac-2 could detect antigen in fixed sections, but that Mac-1 was destroyed by fixation, therefore this antibody was used as a negative control. Sections were incubated for 30 minutes and rinsed three times with PBS. They were overlaid with a bio- 
tinylated polyclonal goat anti-rat Ig (Sigma) for 30 minutes. After three rinsing, sections were further incubated for 30 minutes with a solution of avidin-peroxidase (1:100) (Sigma). Peroxydase activity was detected with diaminobenzidine (DAB, Sigma) $(1 \mathrm{mg} / \mathrm{ml})$ in PBS and $0.03 \% \mathrm{H}_{2} \mathrm{O}_{2}$ in PBS. Slides were washed three times, fixed with methanol and counterstained by the Giemsa-colophonium method to detect malaria parasites.

Several cells containing vesicles with merozoites were seen (data not shown) stained with the Mac-2 antigen while no staining was observed with the Mac-1 antigen, confirming that the host cell belong to the monocytemacrophage lineage.

\section{DISCUSSION}

he destruction of malaria parasites in the liver, the spleen and the lymph nodes is a wellknown phenomenon and some of its biological implications were discussed by Arese et al. (1991). However, it appears that besides this role in clearing the blood, they may store infective stages which will be released later. In our opinion the above described forms may represent resting stages which, when freed from their host cell, are still infective.

The storing of merozoites by macrophages has been observed with the intestinal coccidia. Box (1977) and Grulet et al. (1986) described endomerozoites and "resting trophozoites " in the macrophages of the blood and various organs of several species of Isospora of birds. These forms were thought to play a role in the circadian rhythm of development of the coccidia and to reinfect the intestinal epithelium every 24 hours (Grulet et al., 1986).

Boulard et al. (1996) described a picture seen by electron microscopy of a merozoite adhering to the surface of what they thought to be a dendritic cell.

Many problems remain to be solved. Are the macrophages the ones which store and transport merozoites of a special type? When and where do they engulf the schizonts? When and where do they release them? Finally, from a general point of view, it is obvious that the location of malaria parasites in the general lymphatic system i. e. the lymph vessels, leaves at present many open questions. They are, however, the key to understanding the fine mechanisms of the latency of merozoites, the chronobiology of the malaria parasites and the biological aspect of the drug resistance. They probably also play a role in the immune response.

\section{ACKNOWLEDGEMENTS}

We are very grateful to G. Snounou and H. Ginsburg for their comments and help.

\section{REFERENCES}

Arese P., Turrini F. \& Ginsburg H. Erythrophagocytosis in Malaria: Host Defence or Menace to the Macrophage? Parasitology Today, 1991, 7, 25-28.

Boulard Y., Coquelin F., Mora-Silvera E., Renia L., Gautret P., Deharo E., Snounou G., Vuong P., Chabaud A. \& Landau I. Dendritic leucocytes as possible carriers of murine Plasmodium merozoites. Preliminary note. Parasite, 1996, 3, 383-386.

Box E.D. Life cycle of two Isospora species in the Canary Serinus canarius Linnaeus. Journal of Protozoology, 1977, 24, 57- 67.

Grulet O., Landau I., Millet P. \& Baccam D. Les Isospora du moineau. II. Études sur la biologie. Annales de Parasitologie humaine et comparée, 1986, 61, 161-192.

Ho M.-K. \& Springer T.A. Preparation and use of monoclonal antimacrophage antibodies. Methods in Enzymology, 1984, $108,313-324$.

Johnson J.G. Epstein N., Shiroishi T. \& Miller L.H. Factors affecting the ability of isolated Plasmodium knowlesi merozoites to attach to and invade erythrocytes. Parasitology, 1980, 80, 539-550.

LANDAU I. \& Chabaud A.G. Latency of Plasmodium merozoites and drug-resistance. A review. Parasite, 1994, 1, 105-114.

Landau I., Chabaud A.G., Vuong P.N., Deharo E. \& Gautret P. Circulation in the lymphatic system and latency of Plasmodium merozoites. Preliminary note. Parasite, 1995, 2, 185-186.
Reçu le 3 octobre 1996

Accepté le 31 janvier 199 